\title{
The Effects of Writing a Gratitude Diary and Sharing Thoughts on the Psychological Well-being of the Students
}

\author{
Inseon Yun ${ }^{1}$, Mun-Koo Kang ${ }^{2}$ \\ ${ }^{1}$ Student, Dept. of English Education, Kongju National University, 56 Gongjudaeha \\ -ro, Gongju-si, Chungnam-do, South Korea, yys79@hanmail.net \\ ${ }^{2}$ Professor, Dept. of English Education, Kongju National University, 56 Gongjudaehak-ro, Gongju-si, \\ Chungnam-do, South Korea, kangmunkoo@ hanmail.net
}

Corresponding author: Mun-Koo Kang

\begin{abstract}
The purpose of this study is to develop a specific program that can promote the psychological well-being of middle school students by studying 27 third-grade middle school girls in Daejeon in three groups according to their wishes. Gratitude diaries allowed the researcher to record 12 gratitude statements and three short sentences in 4 weeks. Unlike comparison groups, experimental groups shared their gratitude contents with researchers and participants for 20 minutes a week and conducted follow-up tests. The results of the tests were analyzed through SPSS20 and SAS5.2 and one-way ANOVA using a general linear model was conducted after obtaining the average and standard deviation of gratitude propensity, kindness propensity, psychological well-being, and comparison groups with independent variables. A summary of the main findings of this study is as follows: As a result of Study 1, it was confirmed that writing gratitude diaries and sharing of thoughts did not have a significant impact on individuals' audit tendencies due to statistical figures, but they increased their tendency to be kind. Although writing gratitude diaries and sharing of thoughts did not bring significant differences between groups in middle school students' gratitude tendencies, it was confirmed that the experimental group had the highest gratitude tendency before and after conducting activities. In addition, writing gratitude diaries and sharing of thoughts brought very significant differences between groups in middle school students' tendencies of kindness. What should be noted in this study was that the average of the difference between pre- and post-testing of control groups responded positively even though they did not engage in writing gratitude diaries and sharing of thoughts. In Study 2, it was confirmed that writing gratitude diaries and sharing of thoughts had a positive effect on individual psychological well-being compared to comparative groups. Participants can see that psychological well-being has been enhanced by finding the importance and appreciation of the environment surrounding them. In addition, it was analyzed that sharing contents has a significant effect on the self-acceptance and autonomy factors of psychological well-being.
\end{abstract}

Keywords: Writing a Gratitude Diary, Gratitude Tendency, Kindness Propensity, Psychological Well-being

\section{Introduction}

\subsection{Purpose and Necessity of Research}

Received: December 10, 2020; $1^{\text {st }}$ Review Result: January 23, 2021; $2^{\text {nd }}$ Review Result: March 15, 2021 Accepted: April 30, 2021 
The average happiness level of South Korea measured for three years from 2012 to 2014 ranked 47th out of 158 countries, and 58th in the last three years (2013-2015)[1]. In this situation, the proportion of teenagers who reported having felt sad or hopeless enough to interfere with their daily lives accounted for $32.1 \%$ of men and $43.5 \%$ of women, accounting for $40 \%$ of teenagers[1]. Recent research and active psychology understand mental health as a state where individual strengths and abilities are expressed as much as possible, not as a lack of defects and damage, and suggest mental health growth models seeking individual happiness and growth as an alternative to disease models[2]. In response, the researcher chose two strengths: gratitude and kindness (good deeds) to write a gratitude diary and share her thoughts 12 times over four weeks, and then to verify the effectiveness by measuring gratitude tendencies, kindness tendencies, and psychological well-being. This study is intended to solve the difficulties of limited friendship due to the academic stress that teenagers are experiencing and lack of communication with friends.

\subsection{Research Hypothesis}

Research hypothesis 1 - Writing a gratitude diary and sharing one's thoughts on the individual's appreciation and it will have the following effects:

1-1. Writing a diary of good deeds and gratitude and sharing your thoughts will increase the tendency of gratitude.

1-2. Writing a journal of good deeds and gratitude and sharing your thoughts will increase your kindness.

Research hypothesis 2 - Writing a gratitude diary and sharing one's thoughts on the psychological well- being of an individual:

It will have the following effects:

2-1. The experimental group and the comparative group that conducted the gratitude diary will have a higher psychological sense of well-being than the control group.

2-2. The experimental group that conducted the speech sharing would have higher psychological well-being than the comparative group that did not.

\section{Research Method}

\subsection{Subject to study}

The subjects of this study were 27 female students in a third-grade middle school class located in the old downtown of Daejeon.

[Table 1] Subjects to Study

\begin{tabular}{ccc}
\hline Sortation & Programs & Numbers \\
\hline Experimental group & Writing gratitude diary and sharing the thoughts & 9 \\
Comparison Group & Writing gratitude diary & 9 \\
Control Group & None & 9 \\
\hline & Total & 27 \\
\hline
\end{tabular}


[Table 2] Ratio of the Composition of Research Subjects according to Birth Order, Grade, and Religion

\begin{tabular}{|c|c|c|c|c|c|}
\hline \multicolumn{2}{|c|}{ Group Item } & $\begin{array}{c}\text { Number of } \\
\text { experimental group } \\
\text { cases }(\%)\end{array}$ & $\begin{array}{c}\text { Number of } \\
\text { comparison } \\
\text { group cases } \\
(\%)\end{array}$ & $\begin{array}{l}\text { Number of Control group } \\
\text { cases } \\
(\%)\end{array}$ & Total cases $(\%)$ \\
\hline \multirow{4}{*}{$\begin{array}{l}\text { Birth } \\
\text { order }\end{array}$} & First & $2(22.2)$ & $4(44.4)$ & $4(44.4)$ & $10(37.0)$ \\
\hline & Second & $2(22.2)$ & $3(33.3)$ & $3(33.3)$ & $8(29.6)$ \\
\hline & Third & $1(11.1)$ & $1(11.1)$ & $1(11.1)$ & $3(11.1)$ \\
\hline & $\begin{array}{c}\text { The } \\
\text { youngest }\end{array}$ & $4(44.4)$ & $1(11.1)$ & $1(11.1)$ & $6(27.3)$ \\
\hline \multicolumn{2}{|c|}{ Subtotal } & 9 & 9 & 9 & 27 \\
\hline \multirow{3}{*}{ Grade } & High & $6(66.7)$ & $3(33.3)$ & $0(0)$ & $9(33.3)$ \\
\hline & Mid & $2(22.2)$ & $2(22.2)$ & $5(55.6)$ & $9(33.3)$ \\
\hline & Low & $1(11.1)$ & $4(44.4)$ & $4(44.4)$ & $9(33.3)$ \\
\hline \multicolumn{2}{|c|}{ Subtotal } & 9 & 9 & 9 & 27 \\
\hline \multirow{2}{*}{ Religion } & Yes & $4(44.4)$ & $2(22.2)$ & $3(33.3)$ & $9(33.3)$ \\
\hline & No & $5(55.6)$ & $7(77.8)$ & $6(66.7)$ & $18(66.7)$ \\
\hline \multicolumn{2}{|c|}{ Subtotal } & 9 & 9 & 9 & 27 \\
\hline
\end{tabular}

\subsection{Research Design and Research Procedures}

In this study, two independent variables: gratitude tendency, kindness propensity, and psychological well-being, based on gratitude diary writing and sharing, were determined by the mean and standard deviation of each group. The collected data were analyzed using SPSS20 and SAS5.2.

[Table 3] Study Design

$\begin{array}{lll}\text { Experiemental Group } & \text { O1 X Y O2 } \\ \text { Comparison Group } & \mathrm{O} 3 \mathrm{X} & \mathrm{O} 4 \\ \text { Control Group } & \mathrm{O} 5 & \mathrm{O} 6\end{array}$

O1, O3, O5: Pre-inspection (gratitude, kindness, psychological well-being, interpersonal satisfaction)

O2, O4, O6: Post-inspection (gratitude, kindness, psychological well-being, interpersonal satisfaction)

X: Writing gratitude diary Y: Sharing the content of gratitude

After conducting preliminary tests on 27 middle school girls in the old city center of Daejeon, they were divided into three groups: an experimental group, a comparative group, and a control group. The experimental group and a comparative group would write 12 times in 4 weeks. The experimental group conducted a 20-minute weekly meeting with researchers and group members to share their 
thoughts on the contents of the gratitude. Gratitude diaries were to be filled out in three sentences: the date, the contents of the good deed, and the contents of the good deed, and the feelings of the good deed. They were written in one or two sentences. Four weeks later, the experimental group, comparative group, and control group all performed the same post-test as the pre-test.

[Table 4] Research Procedures

\begin{tabular}{|c|c|c|}
\hline $\begin{array}{l}\text { Research } \\
\text { Step }\end{array}$ & Content & Period \\
\hline $\begin{array}{c}\text { Pre- } \\
\text { inspection }\end{array}$ & Gratitude tendencies, kindness tendencies, and psychological well-being & 2016.09.12. \\
\hline Groups & $\begin{array}{l}\text { Each of the nine members shall be comprised of an experimental group, a } \\
\text { comparative group, and a control group, according to their wishes. }\end{array}$ & 2016.09.13 \\
\hline Programs & $\begin{array}{l}\text { Experimental group: Gratitude diary ( } 3 \text { times a week), and sharing the } \\
\text { thoughts (once a week) } \\
\text { - Comparison group: Gratitude diary ( } 3 \text { times a week) } \\
\text {. Control group: None }\end{array}$ & $\begin{array}{c}2016.09 .19 . \\
\sim \\
2016.10 .16 .\end{array}$ \\
\hline $\begin{array}{c}\text { Post- } \\
\text { inspection }\end{array}$ & Gratitude tendencies, kindness tendencies, and psychological well-being & 2016.10.17. \\
\hline
\end{tabular}

[Table 5] Programs

\begin{tabular}{|c|c|}
\hline Groups & Programs \\
\hline $\begin{array}{l}\text { Experimental } \\
\text { group }\end{array}$ & $\begin{array}{l}1 \text { good deed and } 3 \text { gratitude contents, Write the thoughts in the gratitude diary ( } 3 \text { times a week) } \\
\text { - Conduct a 20-minute speech sharing with researchers and group members in the counseling room once a week } \\
\text { share the contents and feelings of the gratitude(once a week). }\end{array}$ \\
\hline $\begin{array}{l}\text { Comparison } \\
\text { group }\end{array}$ & $\begin{array}{l}1 \text { good deed and } 3 \text { gratitude contents, Write the thoughts in the gratitude diary ( } 3 \text { times a week) } \\
\text { Don't share the thoughts }\end{array}$ \\
\hline Control group & $\begin{array}{l}\text { Not writing a gratitude diary. } \\
\text {. Don't share the thoughts }\end{array}$ \\
\hline
\end{tabular}

\subsection{Measurement Tools}

\subsubsection{Gratitude tendency scale(K-GQ-6)}

The Gratitude Questionnaire-6: GQ-6 developed by McCullough et al. (2002) used the K-GQ-6 translated by Sunjung et al. (2006) in Korean. In this study, a five-point Likert scale was used by Kim Mi-jung (2009) to help middle school students understand. In a study of middle school students by Kim Mi-jung (2009), Cronbach's coefficient was reported to be .80[3-5].

[Table 6] Gratitude Tendency Scale (K-GQ-6)

\begin{tabular}{c|c|c}
\hline \multirow{2}{*}{$\begin{array}{c}\text { Gratitude Tendency Scale } \\
\text { (K-GQ-6) }\end{array}$} & Question number $(*$ is reverse scoring) & Number of questions \\
\cline { 2 - 3 } & $1,2,3 *, 4,5,6 *$ & 6 \\
\hline
\end{tabular}




\subsubsection{A Measure of Kindness}

It consists of a total of six questions and uses a five-point Likert scale of one to five points[6].

[Table 7] A Measure of Kindness

\begin{tabular}{l|c|c}
\hline \multirow{2}{*}{ A measure of kindness } & Question number $(*$ is reverse scoring) & Number of questions \\
\cline { 2 - 3 } & $1,2,3,4,5,6$ & 6 \\
\hline
\end{tabular}

\subsubsection{A Psychological Measure of Well-being}

[Table 8] Psychological Well-being Measure (Kim Ki-hyung, 2006)

\begin{tabular}{llc}
\hline Components & Question number $(*$ is reverse scoring) & Number of question \\
\hline Personal growth & $1^{*}, 16^{*}, 24,27^{*}, 29^{*}, 33^{*}$ & 6 \\
Self-acceptance & $2,6,13,18,28,30$ & 6 \\
Positive interpersonal relationship & $3^{*}, 7^{*}, 14^{*}, 20,34^{*}$ & 5 \\
Autonomy & $4.10,15^{*}, 22,26^{*}, 31$ & 6 \\
Purpose of life & $5^{*}, 8^{*}, 12^{*}, 17^{*}, 21,25$ & 6 \\
Control over the environment & $9,11^{*}, 19,23,32$ & 5 \\
\hline & Total & 34 \\
\hline
\end{tabular}

In order to measure psychological well-being, Ryff (1989), Kim Myung-so, Kim Hye-won, and Cha Kyung-ho translated the Psychological Well-being Scale (PWBS) developed into Korean, and Kim Ki-hyung used a five-point Likert scale[7-9].

\subsection{Data Analysis Method}

First, the data collected in this study were statistically processed using the PSS20 and SAS5.2 systems. Second, a one-way ANOVA (one-way ANOVA) was conducted using F verification for pre-, post-, and difference tests conducted on experimental groups, comparative groups, and control groups to find out the impact of gratitude diaries on psychological well-being. Third, the statistical method for measuring the reliability of the test tool was using the Cronbach's a. The students who participated in the study understood the purpose of the study and agreed to include personal information. However, this study did not include a significant number of students, and it was conducted on middle school students only, thus, it is difficult to generalize the overall results.

\section{Research Results}

This study was conducted to find out the effect of writing gratitude diaries and sharing thoughts on the psychological well-being of middle school students. 


\subsection{Analyze Test Response}

\subsubsection{The Impact of Writing a Gratitude Diary and Sharing the Thoughts on a Gratitude Propensity}

The results of the analysis of variance in [Table 10] show that the F value is 0.20 and that there is no significant difference between groups with gratitude propensity at the significance level of 0.05 . The result of this study is to reject the <Research Theory 1-1>, which says, "Writing a good conduct and gratitude diary and sharing the thoughts will increase the gratitude tendency."

[Table 9] Gratitude Pre-post-difference Verification Average and Standard Deviation

\begin{tabular}{cccccc}
\hline $\begin{array}{c}\text { Dependent } \\
\text { variable }\end{array}$ & Groups & Cases & $\begin{array}{c}\text { Pre- } \\
\text { Mean(SD) }\end{array}$ & $\begin{array}{c}\text { Post- } \\
\text { Mean(SD) }\end{array}$ & $\begin{array}{c}\text { Difference- } \\
\text { Mean(SD) }\end{array}$ \\
\hline $\begin{array}{c}\text { Gratitude } \\
\text { tendency }\end{array}$ & All & 27 & $3,62(0.85)$ & $3.08(0.40)$ & $-0.53(0.66)$ \\
& Comparison & 9 & $4.07(0.69)$ & $3.44(0.16)$ & $-0.63(0.64)$ \\
& Control & 9 & $3.41(1.02)$ & $2.98(0.43)$ & $-0.43(0.75)$ \\
\hline
\end{tabular}

[Table 10] Verification of Gratitude Propensity Differences (ANOVA)

\begin{tabular}{ccccc}
\hline Dispersion source & $\begin{array}{c}\text { Degrees of } \\
\text { freedom (df) }\end{array}$ & Sum of squares (SS) & Mean square (MS) & F \\
\hline Gratitude tendency & 2 & 0.19135802 & 0.09567901 & 0.46733539 \\
Error & 24 & 11.21604938 & \\
\hline All & 26 & 11.40740741 & \\
\hline
\end{tabular}

$* \mathrm{p}<.05, * * \mathrm{p}<.01, * * * \mathrm{p}<.001$

\subsubsection{The Effect of Writing a Journal of Good Deeds and Gratitude and Sharing the Thoughts on the Propensity}

The results of the analysis of variance in [Table 12] show that the $\mathrm{F}$ value is 6.89 and the significant probability is 0.0043 , with significant differences between groups at the significance level of 0.05 . These findings support the <Research Theory 1-2>, which states, "Writing a good deed and gratitude diary and sharing your thoughts will increase your kindness."

[Table 11] Pre-post-difference Verification Average and Standard Deviation of Kindness Propensity

\begin{tabular}{cccccc}
\hline $\begin{array}{c}\text { Dependent } \\
\text { variable }\end{array}$ & Groups & Cases & $\begin{array}{c}\text { Pre- } \\
\text { Mean(SD) }\end{array}$ & $\begin{array}{c}\text { Post- } \\
\text { Mean(SD) }\end{array}$ & $\begin{array}{c}\text { Difference } \\
\text { Mean(SD) }\end{array}$ \\
\hline $\begin{array}{c}\text { Kindness } \\
\text { propensity }\end{array}$ & All & 27 & $3.15(0.68)$ & $3.56(0.65)$ & $0.41(0.56)$ \\
& Comperiment & 9 & $3.26(0.82)$ & $4.09(0.57)$ & $0.83(0.37)$ \\
& Control & 9 & $3.07(0.50)$ & $3.44(0.57)$ & $0.37(0.37)$ \\
\hline
\end{tabular}


[Table 12] Verification of Kindness Propensity Differences (ANOVA)

\begin{tabular}{ccccc}
\hline Dispersion source & $\begin{array}{c}\text { Degrees of } \\
\text { freedom }(\mathrm{df})\end{array}$ & Sum of squares (SS) & Mean square (MS) & F \\
\hline $\begin{array}{c}\text { A disposition for } \\
\text { kindness }\end{array}$ & 2 & 3.00617284 & 1.50308642 & $6.89^{* * *}$ \\
Error & 24 & 5.23456790 & 0.21810700 \\
\hline All & 26 & 8.24074074 & \\
\hline
\end{tabular}

$* \mathrm{p}<.05, * * \mathrm{p}<.01, * * * \mathrm{p}<.001$

3.1.3 Effects of Writing a Prior and Gratitude Diary and Sharing the Thoughts on Psychological Wellbeing

\subsubsection{Statistical Analysis of Psychological Well-being}

The following results reject the "Study hypothesis 2-1" that "the experimental group and the comparative group that conducted the pre-execution and gratitude diary will have a higher psychological well-being than the control group," and support the "Study hypothesis 2-2" that "the experimental group that conducted the sharing will have a higher psychological well-being."

[Table 13] Pre-post-difference Verification Average and Standard Deviation of Psychological Well-being

\begin{tabular}{lccccc}
\hline Dependent variable & Groups & Cases & $\begin{array}{c}\text { Pre- } \\
\text { Mean(SD) }\end{array}$ & $\begin{array}{c}\text { Post- } \\
\text { Mean(SD) }\end{array}$ & $\begin{array}{c}\text { difference } \\
\text { Mean(SD) }\end{array}$ \\
\hline $\begin{array}{c}\text { All } \\
\text { Psychological well- } \\
\text { being }\end{array}$ & Experiment & 9 & $2.99(0.42)$ & $2.95(0.24)$ & $-0.05(0.33)$ \\
& Comparison & 9 & $2.89(0.26)$ & $2.99(0.21)$ & $0.10(0.28)$ \\
& Control & 9 & $3.02(0.57)$ & $2.89(0.24)$ & $-0.13(0.49)$ \\
\hline
\end{tabular}

$* \mathrm{p}<.05, * * \mathrm{p}<.01, * * * \mathrm{p}<.001$

[Table 14] Verification of Differences in Psychological Well-being (ANOVA)

\begin{tabular}{ccccc}
\hline Dispersion source & $\begin{array}{c}\text { Degrees of } \\
\text { freedom (df) }\end{array}$ & Sum of squares (SS) & Mean square (MS) & F \\
\hline $\begin{array}{c}\text { Psychological well- } \\
\text { being } \\
\text { Error }\end{array}$ & 2 & 0.28793096 & 0.14396548 & 0.11278521 \\
\hline All & 24 & 2.70684499 & \\
\hline
\end{tabular}




\subsubsection{Analysis of Psychological Well-being Components}

[Table 15] Average and Standard Deviation of Psychological Well-being Components in the Experimental Group

\begin{tabular}{|c|c|c|c|c|c|}
\hline $\begin{array}{l}\text { Dependent } \\
\text { variable }\end{array}$ & Component & Cases & $\begin{array}{c}\text { Pre- } \\
\text { Mean(SD) }\end{array}$ & $\begin{array}{c}\text { Post- } \\
\text { Mean(SD) }\end{array}$ & $\begin{array}{l}\text { Difference- } \\
\text { Mean(SD) }\end{array}$ \\
\hline \multirow{6}{*}{$\begin{array}{l}\text { Psychologica } \\
1 \text { well-being }\end{array}$} & Personal growth & \multirow{6}{*}{9} & $3.26(0.75)$ & $2.74(0.47)$ & $-0.52(1.17)$ \\
\hline & Self-acceptance & & $3.24(0.80)$ & $3.78(0.58)$ & $0.54(0.32)$ \\
\hline & $\begin{array}{l}\text { Positive interpersonal } \\
\text { relationship }\end{array}$ & & $3.47(0.58)$ & $2.27(0.70)$ & $-1.20(1.13)$ \\
\hline & Autonomy & & $2.83(0.62)$ & $3.19(0.30)$ & $0.35(0.59)$ \\
\hline & Purpose of life & & $3.35(0.74)$ & $2.56(0.41)$ & $-0.80(1.00)$ \\
\hline & Control over the environment & & $3.11(0.43)$ & $3.40(0.5)$ & $0.29(0.24)$ \\
\hline
\end{tabular}

[Table 16] Average and Standard Deviation of Psychological Well-being Components in Comparative Groups

\begin{tabular}{|c|c|c|c|c|c|}
\hline Dependent variable & Component & Cases & $\begin{array}{c}\text { Pre- } \\
\text { Mean(SD) }\end{array}$ & $\begin{array}{c}\text { Post- } \\
\text { Mean(SD) }\end{array}$ & $\begin{array}{l}\text { Difference- } \\
\text { Mean(SD) }\end{array}$ \\
\hline \multirow{6}{*}{$\begin{array}{l}\text { Psychological } \\
\text { well-being }\end{array}$} & Personal growth & \multirow{6}{*}{9} & $3.28(0.37)$ & $2.72(0.54)$ & $-0.56(0.78)$ \\
\hline & Self-acceptance & & $2.83(0.67)$ & $2.98(0.59)$ & $0.15(0.44)$ \\
\hline & $\begin{array}{l}\text { Positive interpersonal } \\
\text { relationship }\end{array}$ & & $3.22(0.71)$ & $2.91(0.86)$ & $-0.31(1.46)$ \\
\hline & Autonomy & & $3.30(0.44)$ & $3.04(0.27)$ & $-0.26(0.53)$ \\
\hline & Purpose of life & & $3.39(0.66)$ & $2.59(0.23)$ & $-0.86(0.76)$ \\
\hline & $\begin{array}{l}\text { Control over the } \\
\text { environment }\end{array}$ & & $2.73(0.56)$ & $3.11(0.59)$ & $0.38(0.04)$ \\
\hline
\end{tabular}

[Table 17] Average and Standard Deviation of Psychological Well-being Components in Control Groups

\begin{tabular}{|c|c|c|c|c|c|}
\hline Dependent variable & Component & Cases & $\begin{array}{c}\text { Pre- } \\
\text { Mean(SD) }\end{array}$ & $\begin{array}{c}\text { Post- } \\
\text { Mean(SD) }\end{array}$ & $\begin{array}{l}\text { Difference- } \\
\text { Mean(SD) }\end{array}$ \\
\hline \multirow{6}{*}{$\begin{array}{l}\text { Psychological well- } \\
\text { being }\end{array}$} & Personal growth & \multirow{6}{*}{9} & $3.02(0.47)$ & $2.94(0.55)$ & $-0.07(0.98)$ \\
\hline & Self-acceptance & & $3.26(0.74)$ & $3.48(0.71)$ & $0.22(0.30)$ \\
\hline & $\begin{array}{l}\text { Positive interpersonal } \\
\text { relationship }\end{array}$ & & $3.80(0.53)$ & $2.33(0.79)$ & $-1.47(1.28)$ \\
\hline & Autonomy & & $3.15(0.35)$ & $3.04(0.30)$ & $-0.11(0.52)$ \\
\hline & Purpose of life & & $2.96(0.62)$ & $2.63(0.57)$ & $-0.33(1.14)$ \\
\hline & $\begin{array}{l}\text { Control over the } \\
\text { environment }\end{array}$ & & $3.29(0.60)$ & $3.33(0.66)$ & $0.04(0.27)$ \\
\hline
\end{tabular}

Through technology statistics and distributed analysis, <Research hypothesis 2-1> "The experimental group and the comparative group that conducted gratitude diary writing will have a higher psychological sense of well-being than the control group." and <Research hypothesis 2-2> "The 
experimental group that conducted the sharing of thoughts will have a higher psychological well-being than the comparative group that did not." "There is no significant difference in psychological wellbeing between groups that have conducted gratitude diaries, but the difference in variance between groups can be partially summarized in three components of psychological well-being: self-acceptance $(\mathrm{F}=2.95$, significance level 0.0716), autonomy $(\mathrm{F}=2.98$, significance level 0.0698).

\subsection{Conclusions and Summary}

The purpose of this study is to develop a specific program that can promote the psychological wellbeing of middle school students by studying 27 third-grade middle school girls in Daejeon in three groups according to their wishes. The conclusions of the study are as follows.

First of all, the gratitude-oriented pre-post-difference verification showed a negative average, which did not increase the gratitude tendency of each group, but it was confirmed that the experimental group had the highest gratitude tendency before or after the gratitude diary writing activities.

Second, writing a gratitude diary and sharing one's thoughts led to a very significant difference between groups in the tendency of the kindness of middle school students. What should be noted in this study is that the average of the differences in the pre-post-examination of the control group showed a positive response even though they did not write a gratitude diary. This can be interpreted as being influenced by kindness among members of the control group who are in a situation where many researchers experience large and small good deeds for four weeks as a learning community and help or receive them.

Third, it can be partially confirmed that writing a gratitude diary has a positive effect on enhancing the psychological well-being of middle school students in the case of experimental groups. Writing a gratitude diary is an opportunity to discover the importance and gratitude of the environment surrounding him/her and the meeting of human relationships by exploring opportunities to do small good deeds in daily life three times a week. This can be seen as an improvement in the psychological well-being of the meaning of life.

Fourth, the regular sharing of gratitude content and feelings was analyzed to be relatively meaningful in technical statistics in self-acceptance and autonomy of psychological well-being compared to comparison groups, showing a relatively meaningful difference in dominance and selfacceptance of the environment.

Since this study was conducted on middle school students, there is a limitation that the results can change when applied to general high school students or specialized high school students. Although this study has this limitation, it can be meaningful in examining how it has effects on learning through reflection journals as a future research.

\section{References}

[1] Hyun-joo Hong, The effect of the group counseling program on youth depression, hope and optimism, Chonnam National University, Master's Thesis, (2012)

[2] Mang-gyu Kim, Positive Psychology Group Counseling Program's Effect on Youth Self-Respect and Happiness Improvement, Korea University, Master's Thesis, (2020)

[3] M. E. McCullough, J. A. Tsang, R. A. Emmons, The Grateful Disposition: A Conceptual and Empirical Topography, Journal of Personaltity and Social Psychology, (2002), Vol.82, No.1, pp.112-127, DOI: 10.1037//0022-3514.82.1.112

[4] Sun-joong Kwon, Kyo-heon Kim, Hong-seok Lee, Validation of the Korean Version of Gratitude Questionnaire, 
Journal of the Korean Psychological Society: Counseling and Psychotherapy, (2006), Vol.11, No.1, pp.177-190, UCI : G704-000533.2006.11.1.011

[5] Mi-jung Kim, The Effect of the Gratitude Promotion Program on the Subjective Well-being of Middle School Students, Perceived Social Support, and Pychological Adaptation, Chonnam National University, Master's Thesis, (2018)

[6] Seok-man Kwon, Positive Psychology, HakJiSa, (2008)

[7] C. D. Ryff, Happiness is Everything or is it? Explorations on the Meaning of Pychological Well Being, Journal of Personality and Social Psychology, (1989), Vol.57, No.6, pp.1069-1081, https://doi.org/10.1037/00223514.57.6.1069

[8] D. Y. Park, The effect of group counseling in the audit diary on the self-efficacy and interpersonal relationships of elementary school students, Korea University, Master's Thesis, (2013)

[9] Ki-hyung Kim, A high school student, and a college student's family relationship, friendship relationship, school adaptation and psychological well-being relationship, Pusan National University, Master's Thesis, (2020) 